\title{
Lacustrine-fluvial interactions in Australia's Riverine Plains
}

\author{
Justine Kemp ${ }^{\text {a, * }}$, Timothy Pietsch ${ }^{\text {a }}$, Allen Gontz ${ }^{\mathrm{b}}$, Jon Olley ${ }^{\mathrm{a}}$ \\ a Australian Rivers Institute, Griffith University, Nathan, 4111, Queensland, Australia \\ ${ }^{\mathrm{b}}$ Department of Geological Sciences, San Diego State University, San Diego, CA, 92108, USA
}

\section{A R T I C L E IN F O}

\section{Article history:}

Received 7 April 2016

Received in revised form 23 December 2016

Accepted 15 February 2017

Available online $\mathrm{xxx}$

Keywords:

Lake Mungo

Willandra Lakes

Lachlan River

Palaeohydrology

Electromagnetic survey

Palaeochannels

Quaternary

LGM

\begin{abstract}
A B S T R A C T
Climatic forcing of fluvial systems has been a pre-occupation of geomorphological studies in Australia since the 1940s. In the Riverine Plain, southeastern Australia, the stable tectonic setting and absence of glaciation have combined to produce sediment loads that are amongst the lowest in the world. Surficial sediments and landforms exceed $140,000 \mathrm{yr}$ in age, and geomorphological change recorded in the fluvial, fluvio-lacustrine and aeolian features have provided a well-studied record of Quaternary environmental change over the last glacial cycle. The region includes the Willandra Lakes, whose distinctive lunette lakes preserve a history of water-level variations and ecological change that is the cornerstone of Australian Quaternary chronostratigraphy. The lunette sediments also contain an ancient record of human occupation that includes the earliest human fossils yet found on the Australian continent. To date, the lake-level and palaeochannel records in the Lachlan-Willandra system have not been fully integrated, making it difficult to establish the regional significance of hydrological change. Here, we compare the Willandra Lakes environmental record with the morphology and location of fluvial systems in the lower Lachlan. An ancient channel belt of the Lachlan, Willandra Creek, acted as the main feeder channel to Willandra Lakes before channel avulsion caused the lakes to dry out in the late Pleistocene. Electromagnetic surveys, geomorphological and sedimentary evidence are used to reconstruct the evolution of the first new channel belt following the avulsion. Single grain optical dating of floodplain sediments indicates that sedimentation in the new Middle Billabong Palaeochannel had commenced before $18.4 \pm 1.1 \mathrm{ka}$. A second avulsion shifted its upper reaches to the location of the present Lachlan River by $16.2 \pm 0.9 \mathrm{ka}$. The timing of these events is consistent with palaeohydrological records reconstructed from Willandra Lakes and with the record of palaeochannels on the Lachlan River upstream. Willandra Lakes shows high inflows during the Last Glacial Maximum ( $22 \mathrm{ka})$, but their subsequent drying between $20.5 \mathrm{ka}$ and $19 \mathrm{ka}$ was caused by river avulsion rather than regional aridity. This case study highlights the benefits of combining fluvial with lacustrine archives to build complementary records of hydrological change in lowland riverine plains.
\end{abstract}

(C) 2016 Published by Elsevier Ltd.

\section{Introduction}

Sedimentary basins in tectonically stable, continental settings can provide long records of climate change preserved in fluvial-lacustrine sequences. Climatic inferences derived from alluvial stratigraphy are known to be complex because of the numerous factors controlling fluvial development, including internal dynamics and feedback, and the relative sensitivity of rivers to external change (Vandenberghe, 2003). On the other hand, a better understanding of the mechanisms controlling fluvial response in each region arguably is essential for successful management of lowland fluvial landscapes. The Riverine Plains in southeastern Australia cover a sedimentary record dating back to the Palaeocene, with sediment depths $<500 \mathrm{~m}$ that have accumulated under a quiescent erosion regime (Brown, 1989). In western areas, sediments record marine transgressions and coastal deltaic environments in the Miocene, followed by continental sedimentation that includes evidence of the development of aridity in Australia from 1.3 million years ago (Bowler et al., 2006). Through the Quaternary, alternating wet and dry periods produced episodic fluctuations in flu-

\footnotetext{
* Corresponding author.

Email address: j.kemp@griffith.edu.au (J. Kemp)
}

vial and fluvial-derived aeolian, and fluvio-lacustrine sequences with saline and fresh waters (Brown, 1989). The surficial features are impressively ancient and cover more than a full glacial cycle (Page et al., 1996; Bowler et al., 2012). Interpreting the sedimentary archives formed in fluvio-lacustrine environments requires an integrated geomorphological reconstruction and sound chronology. In this paper, we focus on changes in the fluvial environment in the lower Lachlan-Willandra system at the Last Glacial Maximum. We provide new fluvial and chronological evidence of channel migrations away from the Willandra Lakes, which provide a key record of Quaternary environmental change in southeastern Australia. Regional and local signatures in the Willandra Lakes water level curve are inferred from the evidence of fluvial avulsion and the construction of new channel belts. First, we review the development of Quaternary geomorphological research and methods in the Riverine Plain.

In an issue devoted to two decades of research into fluvial archives under the auspices of the Fluvial Archives Group (FLAG) it is appropriate to review progress at classic palaeohydrological sites in various parts of the world. The Riverine Plain, in southeastern Australia, is antipodeal to the well-studied North Atlantic region. It occupies $77,000 \mathrm{~km}^{2}$ of the southern Murray-Darling Basin between the Mallee dunefield and the Great Dividing Range, and includes some of the most important agricultural land in Australia (Fig. 1). Its major 


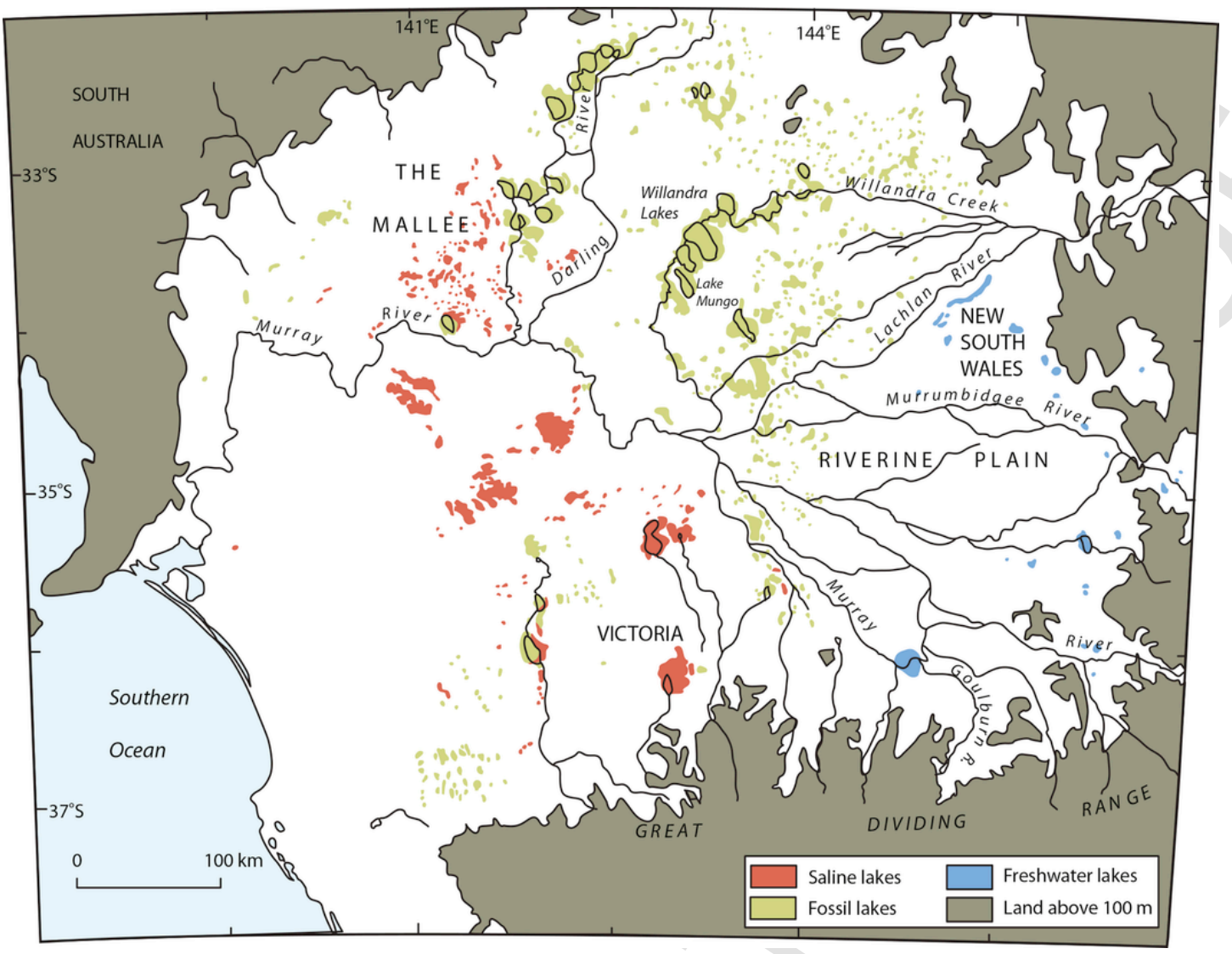

Fig. 1. Location of the Riverine Plain in southeastern Australia showing the major streams and the distribution of fossil and active lakes. Modified from Brown (1989).

rivers, the Murray, Murrumbidgee, Goulburn, and Lachlan, are fed by perennial tributaries that rise in well-watered alpine, subalpine and montane ranges. The streams flow west into semiarid plains, losing water and sediment downstream, many terminating in channel breakdown areas and ephemeral swamps. Under the influence of El Nino-Southern Oscillation and the Indian Ocean Dipole, the high rainfall variability produces floods that inundate tens of thousands of square kilometres, while in drought even the Murray River ceased to flow before the river was regulated in the 1950s (Rutherfurd, 1994; Risbey et al., 2009). In the Pleistocene, temperatures were $9{ }^{\circ} \mathrm{C}$ lower than today (Galloway, 1965; Slee and Shulmeister, 2015), but the headwaters remained virtually unglaciated (Barrows et al., 2001). Extensive periglacial weathering increased the quantity and calibre of sediments transported downstream, but compared to glaciated regions elsewhere around the world, long term sedimentation rates have been low and many Pleistocene landforms are preserved. The stable cratonic setting of the Riverine Plain has allowed climatic influences on river patterns and sedimentation to come to the fore. A distinctive climatic approach to geomorphology emerged amongst those working in the region, cross-fertilised by researchers with experience in Britain, the United States, and Australia.

\subsection{Past studies in the Riverine Plain}

Much of the early interest in the fluvial history of the Riverine Plain was generated by agricultural expansion in the 1940s and 1950 s, which produced systematic attempts to explain the complex patterns of soil types, vegetation and geomorphology (Butler, 1950, 1958; Langford-Smith, 1960; Pels, 1964, 1966). The first aerial pho- tographs revealed that the generally flat terrain broken by low, linear rises and native cypress-studded dunes was an ancient fluvial landscape. Its surficial geomorphology reflected a long history of fluvial interaction with groundwater, fine sediments, and the periodically expanding arid zone, producing a spectrum of sedimentary and geomorphic archives that includes terraces, floodplain lakes, aeolian source-bordering dunes, and fluvial sediments of bedload, mixed and suspended-load rivers. The region is now the most intensively studied fluvial landscape in Australia and has produced a number of classic studies in fluvial geomorphology and palaeohydrological change.

Initially, the stratigraphic associations of soils and geomorphic units were the basis for interpreting landscape evolution, and regionally uniform palaeosols became chronostratigraphic markers in the absence of radiometric dating (Butler, 1958, 1959, 1982). This was formalised as the $\mathrm{K}$-cycle theory $(K=$ kronos $)$ of soil formation and episodic sedimentation, in which periods of instability and erosion alternate with periods of stability and soil formation. While the stratigraphic framework later proved to be diachronous and older than previously assumed, the concept emphasised regional climate controls on landform evolution, and linked geomorphic changes in the uplands with sedimentary effects on the distant plains. K-cycles became widely employed outside Australia to improve understanding of the relationship between pedogenesis and other earth surface processes and is still used today (Schaetzl and Thompson, 2015).

Evidence for a climatic influence on channel pattern was clearly apparent to George Dury (1964a), whose concept of underfit, or misfit, streams was at least partly developed from his experience of channels in the Riverine Plains. The numerous examples of manifest underfitness, with stream meanders superimposed on a larger meander- 
ing trench, suggested higher discharges produced by climates and erosion regimes very different to the present (Dury, 1964b, 1967). This work contributed to vigorous debate on the interpretation of the palaeochannels, which had markedly different sedimentary characteristics, dimensions, aeolian features, and modes of floodplain formation (see Page et al., 2009). Dury (1967) pointed to the correspondence of pluvial lakes with streams of larger dimensions, but confirmation of their co-existence would come only with radiocarbon and luminescence dating of fluvial sediments in the subsequent decades, and is still being resolved (Bowler, 1978; Bowler et al., 1978; Page et al., 1991, 1996; Kemp and Spooner, 2007; Kemp and Rhodes, 2010; Kemp et al., this paper). Dury's experience with Luna Leopold at the US Geological Survey in 1960-61 was likely to have been influential in his attempts to formalise the relationship between climate and channel morphology (Dury, 1976, 1985). His statistical relationships between palaeochannel bankfull discharge, meander wavelength, channel cross-sectional area, and channel width laid the foundations for quantitative palaeohydrology and were applied by Bowler (1978) to newly defined palaeochannel complexes of the Goulburn River.

Further developments in palaeohydrology were made by Stanley Schumm whose empirical relationships between channel shape, sinuosity and sediment type were partly developed from the Murrumbidgee River and its palaeochannels in a classic and influential study (Schumm, 1968). Schumm emphasised the influence of sediment type on all aspects of channel morphology, and included sediment dimensions in his subsequent channel pattern classification (Schumm, 1985). The concept of river adjustment to altered conditions, or as he called it, river metamorphosis, could suitably be pursued in the Riverine Plains where palaeochannel forms presented a sharp contrast in size, sediment characteristics and shape (Schumm, 1969, 1972; 1978). In Schumm's view (1968, 1969), long-term changes in channel morphology and pattern dominantly reflected changes in discharge, sediment type and load in response to climate change, in this case, between arid and humid periods. Channel response was therefore predictable and depended on erosion and climate regimes, and the likely changes in catchment sediment and water yields. This qualitative but multidimensional approach to channel change has been widely and successfully applied to both palaeohydrology and to anthropogenic changes to rivers and catchments (Knighton, 2014).

Despite the groundbreaking work in the 1960s, palaeohydrologic reconstructions in the Riverine Plain have been bedevilled by the fact that Late Quaternary palaeochannels are very different from the modern rivers. For a long time, the suite of large, coarse-textured palaeochannels was considered to be geomorphically more interesting than their modern counterparts, described by one researcher as "mud-lined gutters" (Gill, 1973). In the last 30 years, this situation has been partly redressed. Investigations have showed that the hydrologic and geomorphic characteristics of rivers in the Riverine Plain differed in many ways from those described in North America and Europe, particularly with respect to their bankfull return periods, which were longer than average (Rutherfurd, 1994; Kemp, 2010), and their floodplain geomorphology, which in confined areas showed features routinely shaped by floods that elsewhere would be considered catastrophic events (Kemp, 2004). Their floodplains were constructed by a large component of fine-textured sediments deposited through oblique accretion and through in-channel features such as concave bank benches (Page and Nanson, 1982; Page et al., 2003). Channels are subject to avulsion on a variety of timescales (Schumm et al., 1996; Stone, 2006; Kemp, 2010). Dury's (1976) stereotype relationships based on channel morphology and discharge proved to be a poor predictor of modern bankfull flows (Bowler, 1978). Part of the issue may be that they were designed for expanding channel networks rather than for streams in which channel size decreased downstream. This contrast, between an expanding channel and diminishing slope in conventional drainage basins, compared to steepening slopes and larger channels (i.e. upstream) leads to adjustments of fluvial parameters and downstream hydraulic geometry exponents outside the range of values recorded elsewhere around the world (Kemp in prep.; Pietsch and Nanson, 2011).

The Quaternary chronostratigraphic record for the Riverine Plain has been well documented, owing in large part to three decades of research led by Jim Bowler dedicated to unravelling the riddle of Quaternary environments and palaeoclimates preserved in lacustrine, fluvial and aeolian landforms in continental Australia. Bowler instigated the CLIMates Australian and New Zealand (CLIMANZ: 1980) and Salt Lakes Evaporites and Aeolian DepositS (SLEADS: 1981) programmes, which improved understanding of Quaternary landform evolution and arid zone processes well beyond Australia (Magee and De Deckker, 2001). On the Riverine Plain, lakes formed singly or in chains within modern or ancient channel belts have proved to be valuable archives of hydrological change, particularly the distinctive lunette lakes (Bowler et al., 2006). These kidney-shaped lakes were orientated north-south and enclosed by crescentic aeolian ridges (lunettes) on their eastern margins. In two seminal papers, Bowler $(1971,1973)$ showed that lunette sedimentation is dominated by deflation of beach sand and strong, unidirectional wave action under lake-full conditions, while at low lake levels, clays deflate in sand sized pellets from seasonally exposed mud flats. Evidence for changing lake levels is preserved in the marginal lunette sediments and beaches. The Willandra Lakes preserve the most intensively studied lunette sequence (Fig. 2). This cascading chain of lakes, formed along an ancient channel belt of the Lachlan River, contains evidence for lake levels and fauna extending over more than 140,000 yr (Bowler and Price, 1998; Bowler et al., 2012; Long et al., 2014; Fitzsimmons et al., 2014, 2015; Westaway et al., 2017). The area is listed as a World Heritage Site, and preserves some of Australia's most significant archaeological sites, including the world's oldest recognised ritual burial, and Australia's earliest human fossils at Lake Mungo (Thorne et al., 1999; Bowler et al., 2003; Olley et al., 2006), together with a long record of human resource use based on grinding stones, hearths, middens, shell tools, and fish otoliths (Bowler, 1998; Stern et al., 2013, 2015; Long et al., 2014; Fullagar et al., 2015a, 2015b; Weston et al., 2015). These are key sites in the Australian archaeological record, although river marginal dunes formed by deflation of river bed sands are also beginning to reveal an ancient archaeological record (e.g. Kemp et al., 2014a).

The environmental record from Willandra Lakes remains a cornerstone for the Quaternary chronostratigraphy of southeastern Australia (Reeves et al., 2013; Petherick et al., 2013). Critically, uncertainty surrounds the hydrological conditions during the LGM, when water supply to the lakes was cut off by avulsion of Willandra Creek, which was diverted south towards the Murrumbidgee River (Fig. 2). This permanently changed the lakes' hydrology as well as the intensity of its use by human communities (Bowler, 1998, Bowler et al., 2012; Stern et al., 2013). The timing of avulsion is thought to have coincided with the final drying of the lakes after $19 \mathrm{ka}$ (Bowler et al., 2012; Fitzsimmons et al., 2014). This event provides an opportunity to integrate the lacustrine and fluvial records in a discrete catchment. New data presented here integrates the changes that occurred during the terminal stages of Willandra Lakes with the accompanying fluvial changes in the Lachlan-Willandra distributary network. The chronology is based on new single-grain optically stimulated luminescence ages. This case study provides the basis for a discussion of fluvial 


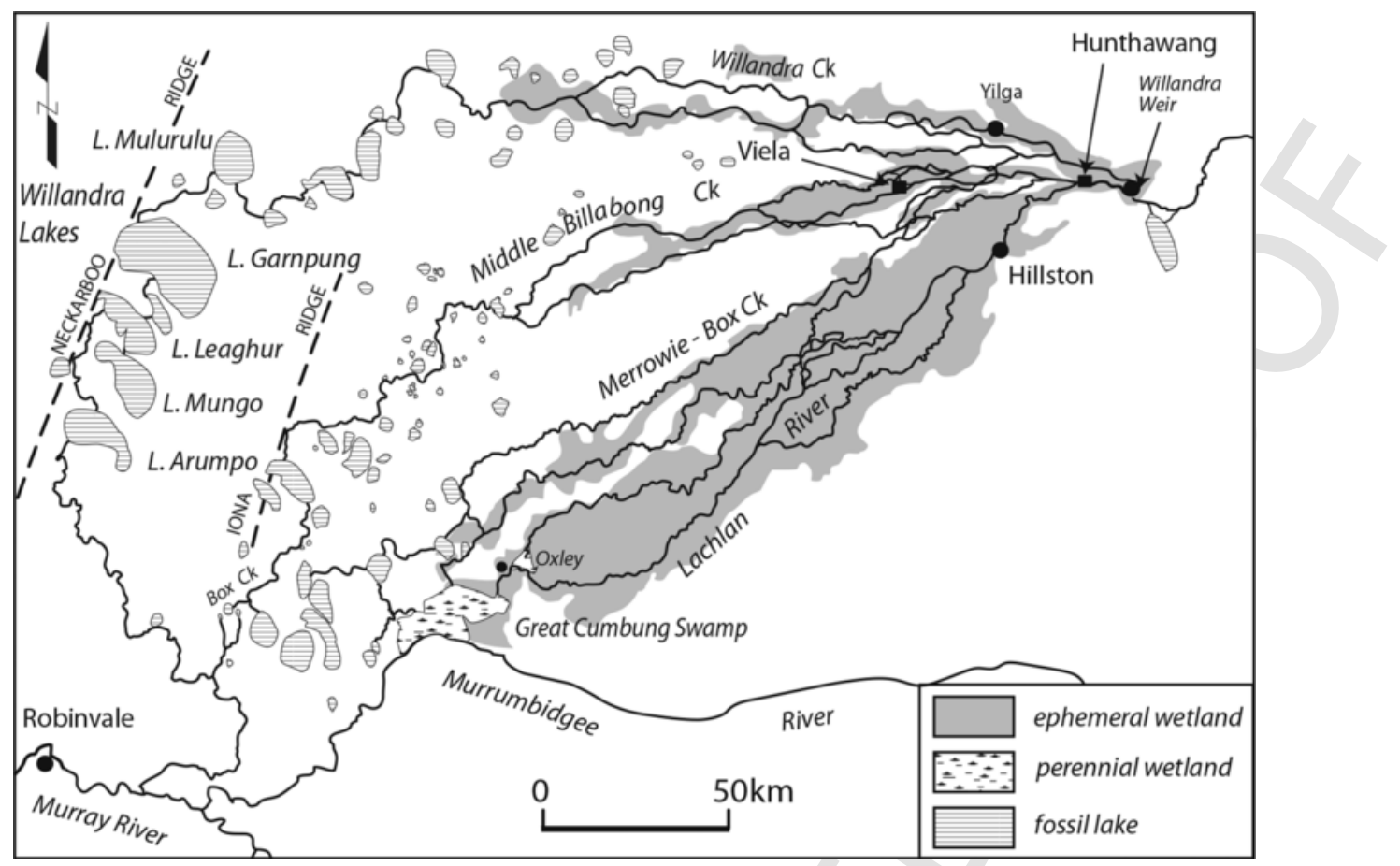

Fig. 2. Streams, lakes, and late Quaternary channel belts of the lower Lachlan River. Based on mapping from satellite images and Butler et al. (1973).

and lacustrine responses to climate and environmental change during the extended Last Glacial Maximum in Australia (35-18 ka).

\subsection{The Lachlan-Willandra system}

The Lachlan River is the northernmost tributary of the Murray Basin with a catchment of $85,000 \mathrm{~km}^{2}$ (Fig. 1). The Lachlan basin lies north of the rich irrigation areas that occupy the land between the Murray and Murrumbidgee Rivers, and therefore escaped much the direct attention devoted to soils and geomorphology of that region. The river drains tablelands and ranges west of the Great Dividing Range at $35^{\circ} \mathrm{S}$ and joins the Murrumbidgee River in the Great Cumbung Swamp, $\sim 500 \mathrm{~km}$ to the west (Fig. 2). Downstream from its highland catchment the tributaries are ephemeral, and the river decreases in size and discharge, developing anabranches as it enters the plains (Kemp, 2010). Downstream from Willandra Weir, distributary channels, including Willandra and Middle Billabong Creeks, divert moderate and flood flows to distal parts of the plain, but fail to reach their confluences with the Murray and Murrumbidgee Rivers, and the lake chains in their lower reaches are dry. Movements of the lower Lachlan River from its northern position at Willandra Creek to more southern parts of the plain are likely owing to gentle tectonic movements along the Ivanhoe Block, a concealed N-NE trending basement ridge complex bounded by faults that run east and west of Willandra Lakes (Fig. 2). The Iona Ridge forms its eastern limb and has been subject to tilting since the Pliocene, with uplift of $45 \mathrm{~m}$ in the north and $5 \mathrm{~m}$ in the south (Kellett, 1989). On the gentle gradients of the Riverine Plains, subtle tectonic influences can have disproportionately large effects, and the Iona Ridge marks a sharp boundary between the western riverine plain and the Mallee dunefield, and separates the Darling groundwater systems from those of the Lachlan-Murrumbidgee. Recent movements on the Ivanhoe Block also deflected the southern outflow of Willandra Lakes from a SSW direction towards the Murray River to a SSE confluence with Box Creek (Kellett, 1989; Fig. 2).

\section{Methods}

2.1 Geomorphic mappingMapping of the fluvial and aeolian landforms of the Riverine Plain was facilitated by the availability of aerial photographs in the 1940s. These provided a uniform basis for mapping across the region, and explained variations in salinity and the winding topography of the overlapping and abandoned channels. Mapping of soil-fluvial units culminated in the Geomorphic Map of the Riverine Plain, and formed the basis for the major stratigraphic units (Butler, 1961; Butler et al., 1973). More recently, the photomosaics and stereoscoped aerial photographs have been supplemented by remotely sensed imagery available in acceptable detail via Google Earth (this paper). Early descriptions of subsurface structures were based on soil surveys and shallow aggregate quarries (Butler, 1958; Schumm, 1968). Targeted boreholes in longitudinal and cross-channel transects enabled more systematic description of palaeochannel phases, which had become known as prior and ancestral streams (Pels, 1964, 1966). These were refined by Bowler (1978) as process-based interpretations from the detailed stratigraphic structures exposed in modern river banks and from the surface morphology of the scrolled meander plains. Natural exposures of older palaeochannel phases were more limited, but Page and Nanson (1996) made use of quarry pits and extensive borehole surveys of government irrigation development areas gathered in the 1960s to develop an improved, comprehensive model of channel evolution for the Murrumbidgee River. Geophysical methods using electromagnetic techniques are proving useful to define the gross morphology of buried channel features (this paper).

Butler et al. (1973) mapped the Lachlan downstream from Willandra Weir at a scale of 1:500,000, distinguishing lakes and source-bordering dunes, and broadly described the morphology of confined and unconfined channel belts. The major geomorphic units in the Lachlan fluvial system were described by Bowler and Magee (1978), but their map did not cover the apex of the distributary network. Preliminary 
fluvial geomorphic maps by Adamson et al. (1987) showed the complexity of anabranches and palaeochannels in pockets of the lower Lachlan. Here, palaeochannels were mapped over $4000 \mathrm{~km}^{2}$ downstream from Willandra Weir using remotely sensed imagery from Google Earth Pro (2015) between Willandra Lakes and the Lachlan River. This was supplemented by the regional map of Butler et al. (1973) in order to show the location of channel belts in the Lachlan's lower reaches. Soil associations on the geomorphic units clearly delineate the edge of the channel belts and the nature of fluvial activity within it, which typically are scrolled floodplains with channels that have been infilled and subsequently modified by smaller flows. The boundaries of the channel belts were identified from the area of scrolled plain produced by lateral channel migration. They are typically well defined, but their complexity increases in areas of anabranching or avulsion. Subsurface stratigraphy was reconstructed from electromagnetic (EM) surveys of channel and floodplain transects and confirmed by hand augered cores to depths of $4 \mathrm{~m}$. Transects across the palaeochannel and floodplain were surveyed using a GF Instruments CMD-Explorer system and integrated high-resolution GPS. The EM data were collected in transects from the scrolled floodplain to the channel, and were subsequently processed using using RES2D software. Transects were processed and inverted. The resultant subsurface representation produced $7.5 \mathrm{~m}$ of penetration. All transects were geo-encoded with spatial data acquired simultaneously with the linked GPS system. Individual profiles were converted to depth-distance, from which sediment thicknesses as well as subsurface architecture were estimated.

The complex history of cross-cutting anabranches was reconstructed from downstream changes in meander geometry, floodplain characteristics, and degree of infilling. Complete abandonment of channel belts is often slow in this landscape, and many palaeochannels continue to function as flood distributaries. The shrunken channels that now occupy Willandra and Middle Billabong Creeks offer testimony to the longevity of channel belts. Channel reworking can be identified from incision and the development of inset floodplains, or the development of underfit, bimodal meander trains. For this reason, channel characteristics and meander geometries were examined in meander cutoffs, where they rapidly become isolated from the main channel and infill with fine overbank sedimentation, offering greater textural contrast with the original bed and bank sediments (Allen, 1965). Evolutionary sequences reconstructed from satellite images were verified in the field wherever possible. Individual arms of the distributary network are named palaeochannels and designated by their modern creek names (e.g. Willandra Palaeochannel). In the middle and upper Lachlan, fluvial systems can be identified by their sediments and morphology, soils, source-bordering dunes (or their absence), their relative dimensions, and their association with terraces, and they are spatially and temporally discrete (Kemp and Rhodes, 2010). In the lower Lachlan the distributary network is complicated by the co-existence of channels of different sizes. Therefore palaeochannels on the distributary arms are attributed to specific fluvial systems only where there is evidence of consistent morphology and sediments, and lateral continuity with palaeochannels upstream. Further work on the chronology and geomorphology of the Lachlan distributary channels will improve many of these associations.

\subsection{Dating methods}

The first absolute chronologies for palaeochannels in the Riverine Plain were based on radiocarbon techniques, which yielded reliable ages for Holocene and Late Glacial age channels (see compilation in Kemp and Rhodes, 2010). Pleistocene channels typically contained smaller quantities of suitable carbon, and radiocarbon ages $>20 \mathrm{ka}$ were suspected of contamination by younger organic compounds contained in the groundwater (Bowler, 1978). This was confirmed when palaeochannel sediments on the Goulburn (Kotupna Complex) radiocarbon-dated at $16-13 \mathrm{k}{ }^{14} \mathrm{C}$ yr BP $(18.5-15 \mathrm{k}$ cal. yr BP) yielded an age of $34 \mathrm{ka}$ using thermoluminescence (TL) techniques (Page et al., 1991). TL ages were used to construct the first chronology of palaeochannels that extended over a glacial cycle, although dates $>90 \mathrm{ka}$ are reported as minimum ages (Page et al., 2001, 1996). TL ages for activity on source-bordering dunes associated with various palaeochannel systems were generally similar to ages for the associated channels, except where dune crests had been reworked (Page et al., 1996). Banerjee et al. (2002) applied small aliquot, optically stimulated luminescence (OSL) techniques to a source-bordering dune on a Murrumbidgee palaeochannel (Yanco Palaeochannel System), which was in general agreement with TL channel and dune ages. A direct test of multiple aliquot and small aliquot OSL techniques was made on a Pleistocene dune and channel of the Lachlan River (Ulgutherie Palaeochannel System), which returned statistically identical ages at one sigma error of $32 \mathrm{ka}$ (Kemp and Spooner, 2007; Kemp and Rhodes, 2010). Here, we present the first single-grain OSL ages for palaeochannels on the Riverine Plain. Detailed explanation of the OSL methods is given in Kemp et al. (2014b) and included in Supplementary Data (Supplementary Data).

\section{Results}

\subsection{Willandra Creek palaeochannel}

The Willandra Palaeochannel can be traced continuously along the Lachlan River from its eastern riverine plains to the Willandra Lakes and below, although its characteristics change as the channel negotiates the Mallee continental dunefield (Fig. 2). Downstream from Willandra Weir, the channel belt trends WNW for $276 \mathrm{~km}$ and turns south into the Willandra Lakes. Dry lake basins of $\sim 20 \mathrm{~km}^{2}$ become common in the lower half of its course and increase in area downstream. The overflow channel from Willandra Lakes reaches a confluence with the Murray River near Robinvale. Near the apex of the distributary network, the channel belt is $1800 \mathrm{~m}$ wide, declining to $800 \mathrm{~m}$ near the beginning of the Willandra Lakes. Near Yilga, the palaeochannel has a wavelength of $\sim 1730 \mathrm{~m}$ compared to $480 \mathrm{~m}$ in the modern channel (Fig. 2). Mapping from satellite imagery and field investigations near Willandra Weir shows that the Willandra channel belt was created by lateral migration of a relatively large channel, followed by channel avulsion, and a staged contraction of the channel and floodplain.

\subsection{Middle Billabong Palaeochannel}

The Middle Billabong Palaeochannel diverges from Willandra Creek $15 \mathrm{~km}$ downstream from Willandra Weir, following an abandoned reach of the Willandra Palaeochannel (Fig. 2). The channel belt runs $210 \mathrm{~km}$ WSW, merging with Middle Billabong Creek $25 \mathrm{~km}$ NW Hillston, and flows toward small lakes in the western part of the basin. Its southwesterly course is defeated by the higher ground of the Iona Ridge and the palaeochannel turns south toward the Murray River (Fig. 2). The lower reaches of the channel belt traverse the longitudinal east-west dunes of the Mallee and the channel is poorly defined and interrupted by numerous, now dry, lake basins. The width of the channel belt in the upper $45 \mathrm{~km}$ averages $1285 \mathrm{~m}$, narrowing to $600 \mathrm{~m}$ as it approaches the Iona Ridge. The scrolled floodplain includes a large palaeochannel with an average meander wave- 
length of $890 \mathrm{~m}$ measured from well formed meanders in the upper $30 \mathrm{~km}$. Floodplain sediments at Viela, $38 \mathrm{~km}$ W Hillston on the Mossgiel Trunk Road (Figs. 2 and 3), consist of a thin, $0.15 \mathrm{~m}$ bed of well sorted, medium sand of the channel bed overlain by $2.6 \mathrm{~m}$ of strong brown, fine sand and silty fine sand fining upwards to $0.6 \mathrm{~m}$ of dark brown silty clay of overbank sediment (Fig. 3b). Sediment underlying the channel bed is moderately well cemented, mottled fine sand with carbonate concretions. The palaeochannel width measured from well preserved palaeochannel segments and from satellite images averages $105 \mathrm{~m}$, and channel depth measured from EM surveys and augerholes (Fig. 3c) measured 2.9, giving a width-depth ratio of 36 . This compares with a width-depth ratio of 4.9 for the modern Lachlan River at Hillston (Fig. 2).
Near Hunthawang, a younger reach of the Middle Billabong Palaeochannel formed after avulsion of its upper reaches from Willandra Weir (Fig. 2). The palaeochannel can be traced along Middle Billabong Creek and merges with the Middle Billabong Palaeochannel $25 \mathrm{~km}$ NW Hillston. At Hunthawang, the scrolled floodplain is inset $1 \mathrm{~m}$ into the plain and lies outside the underfit floodplain of the Lachlan River, which here is narrow and inset within the older meander trace (Fig. 4a). The palaeochannel is regularly sinuous with a ridge and swale topography. Subdued scrolls visible on satellite images have been mapped in Fig. 4a. Palaeomeander wavelength is $\sim 650 \mathrm{~m}$ compared to $\sim 350 \mathrm{~m}$ for the modern Lachlan in the same reach. Sediments along a transect perpendicular to the meander bend apex displayed at least $3.0 \mathrm{~m}$ of lightly mottled, yellowish brown,

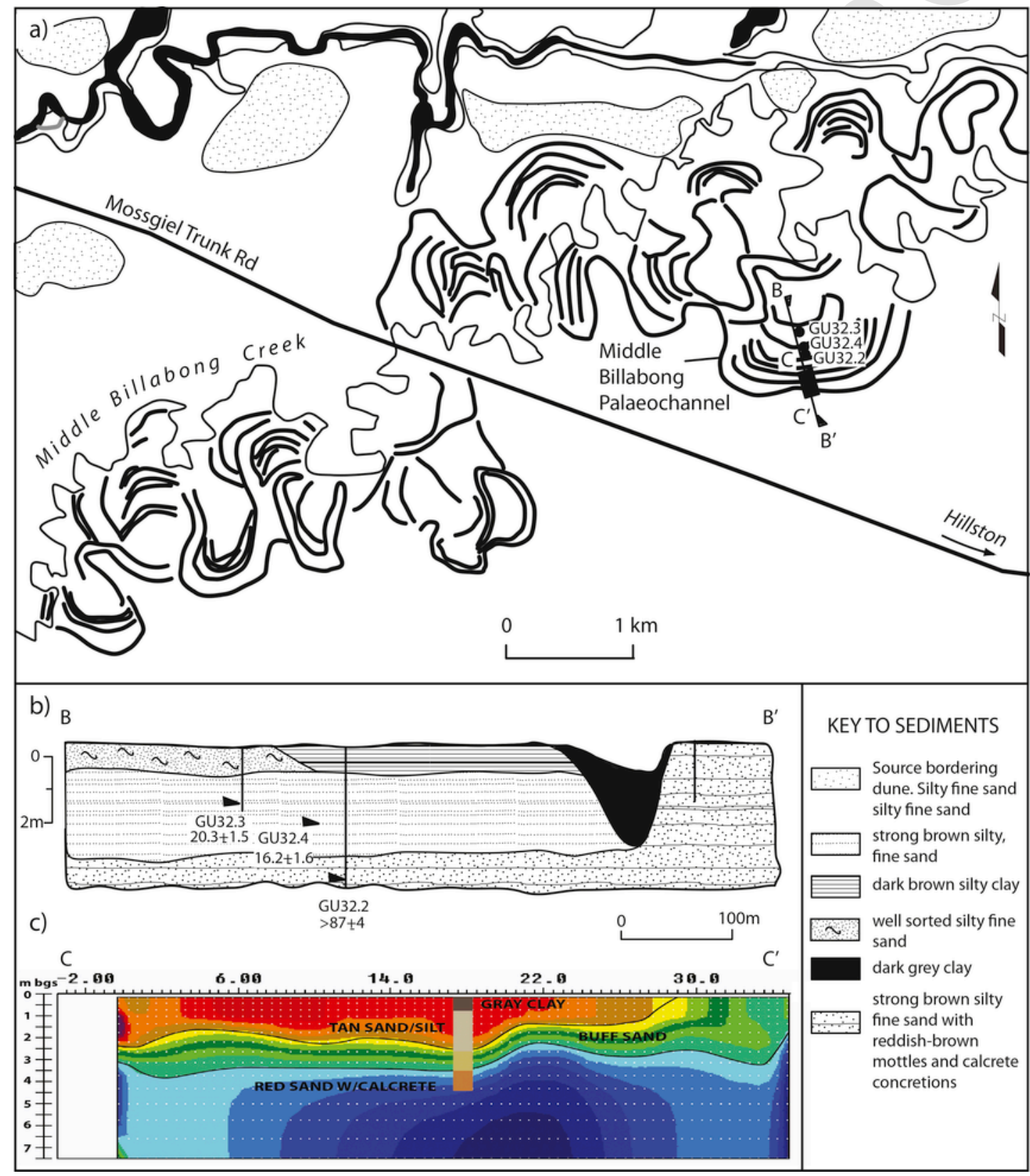

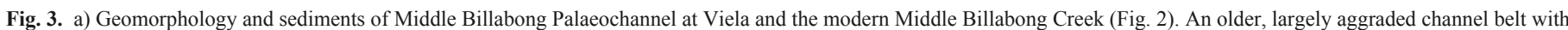

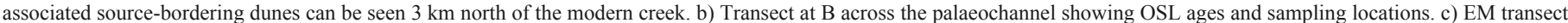
at $\mathrm{C}$ across the infilled palaeochannel shows good agreement with sediment logs. 


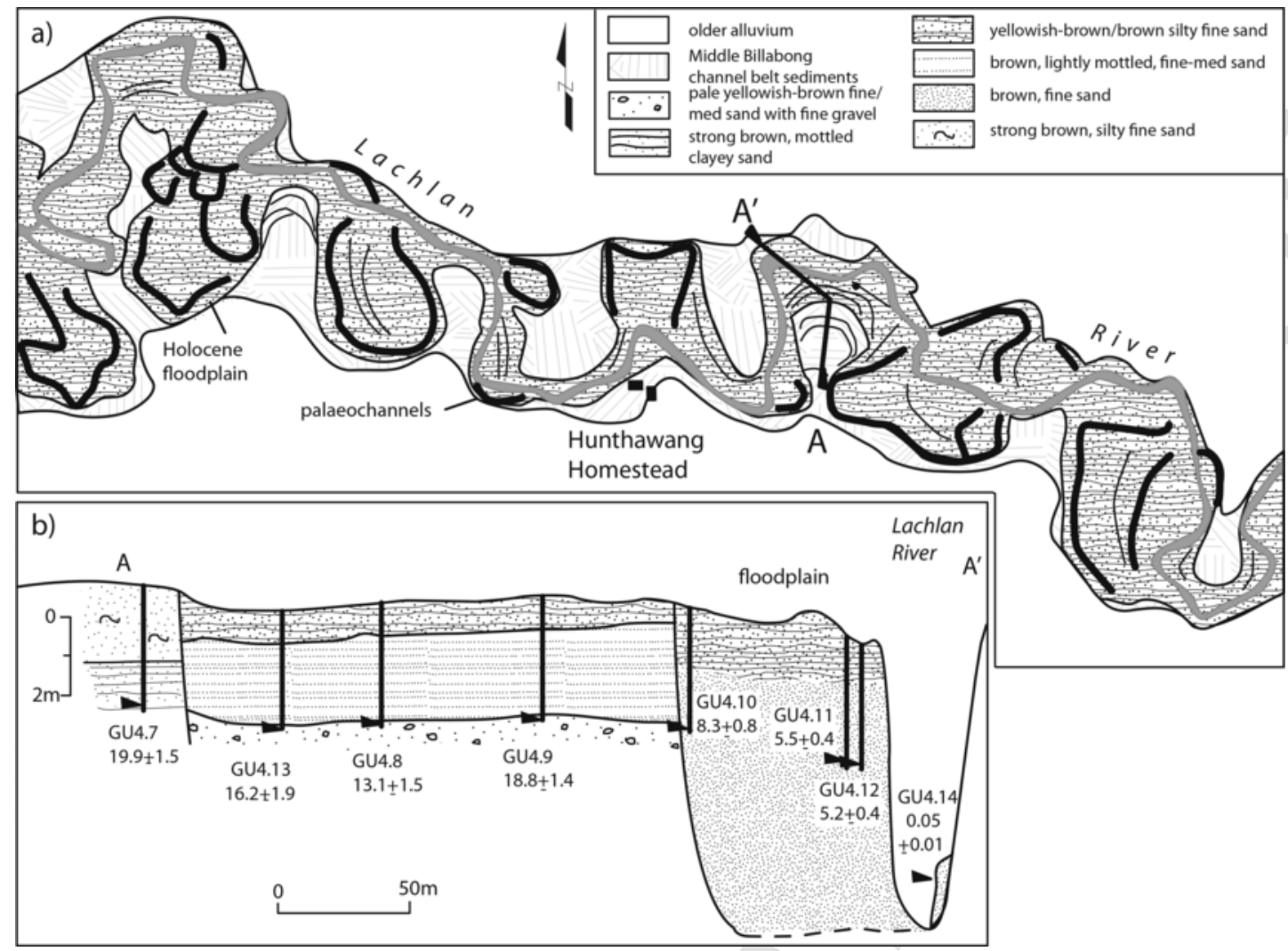

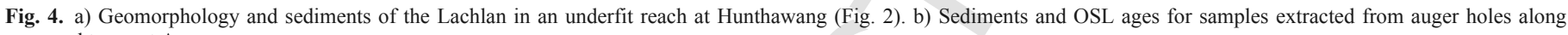
surveyed transect A.

fine and medium sand with rare fine gravel, fining upwards to fine sand with accessory silt in the top $0.2 \mathrm{~m}$ of the old floodplain soil (Fig. $4 \mathrm{~b})$. This is overlain by $0.5-0.8 \mathrm{~m}$ brown, fine silty sand and clayey sandy silt related to recent overbank flooding. Sediments from the surrounding plain were moderately cemented, mottled, strong brown and reddish brown, weathered sand overlain by $1.8 \mathrm{~m}$ strong brown, silty fine and medium sand that may represent levee sediments from the adjacent palaeochannel. The modern floodplain is inset $0.5 \mathrm{~m}$ into the palaeochannel surface and comprises strong brown and brown clayey, silty, fine and medium sand.

At Viela, OSL samples from the scrolled floodplain of the Middle Billabong Palaeochannel were $20.3 \pm 1.5 \mathrm{ka}$ and $16.2 \pm 1.6 \mathrm{ka}$, which are in correct stratigraphic order within the scroll plain, but statistically are similar within $2 \sigma$ errors (Fig. $3 b$; Table S2; Fig. S1). Given the short distance between these samples, the age of sedimentation within the floodplain might be approximated from the weighted mean of these ages, giving a depositional age of $18.4 \pm 1.1 \mathrm{ka}$. The sample from the underlying weathered alluvial sand returned a minimum age of $>87 \pm 4 \mathrm{ka}$ and contained a large number of saturated grains. At Hunthawang, weathered sand from the edge of the terraced plain returned an age of $19.9 \pm 1.5 \mathrm{ka}$ (Fig. 4b; Table S2; Fig. S1). On the ancient scroll plain, progressing from the oldest (inner meander) to youngest (outer meander) sediments the OSL ages were $16.2 \pm 1.9 \mathrm{ka}$, $13.1 \pm 1.5 \mathrm{ka}$ and $18.8 \pm 1.4 \mathrm{ka}$. The weighted mean of these ages suggests an age for sedimentation of $16.2 \pm 0.9 \mathrm{ka}$. Samples from the inset, modern floodplain returned ages of $8.3 \pm 0.8 \mathrm{ka}, 5.2 \pm 0.4 \mathrm{ka}$ and $5.5 \pm 0.4 \mathrm{ka}$. A sample from the in-channel bench within the modern Lachlan channel yielded an age of $0.05 \pm 0.01 \mathrm{ka}$ (Fig. 4b).

The timing of avulsion from Willandra Creek can be approximated by OSL ages for sedimentation on the new channel belts along
Middle Billabong Creek. The oldest OSL ages for these sediments provide a minimum age for this event, assuming development of the new channel belt occurred rapidly. OSL ages for point bar deposits at Viela indicate that sedimentation along the new channel belt (Middle Billabong Palaeochannel) had commenced before $18.4 \pm 1.1 \mathrm{ka}$. Sedimentation in the upper reaches of the Middle Billabong Palaeochannel may have been short-lived before a second avulsion diverted its upper reaches to the location of the present-day Lachlan River at Hunthawang by $16.2 \pm 0.9 \mathrm{ka}$.

\subsection{Discussion 4.1. Links between Lachlan palaeochannels and Willandra Lakes}

Direct comparison of the fluvial record with Willandra Lakes needs to recognise that the lakes form a cascading sequence that overflows at its lower end to the Murray River (Fig. 2; Bowler et al., 2012). The uppermost Lake Mulurulu overflows to Garnpung, which overflows to Leaghur, and then Lake Arumpo. Lake Mungo receives flow from Lake Leaghur via a side channel but does not itself overflow. The system is hydrologically open, except during intermediate and lower lake levels which do not reach the spillover point of Lake Arumpo.

The age of inception of Willandra Creek can not be established here, but evidence from the Lachlan upstream of Condobolin suggests that large, scrolled meanders of the Ulgutherie phase correspond to the Willandra Palaeochannel (Kemp and Spooner, 2007; Kemp and Rhodes, 2010). These were active from $34 \mathrm{ka}$, with sedimentation continuing in a river of declining dimensions until $20 \mathrm{ka}$ (Kemp and Rhodes, 2010; Fig. 5a). The main phase of channel sedimentation in this impressive system can be associated with strandline 
a)

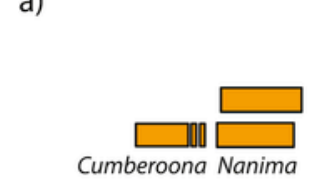

b)
Willandra Lakes cut-off
Lachlan palaeochannels

Lower Lachlan

Middle Lachlan

Willandra Lakes

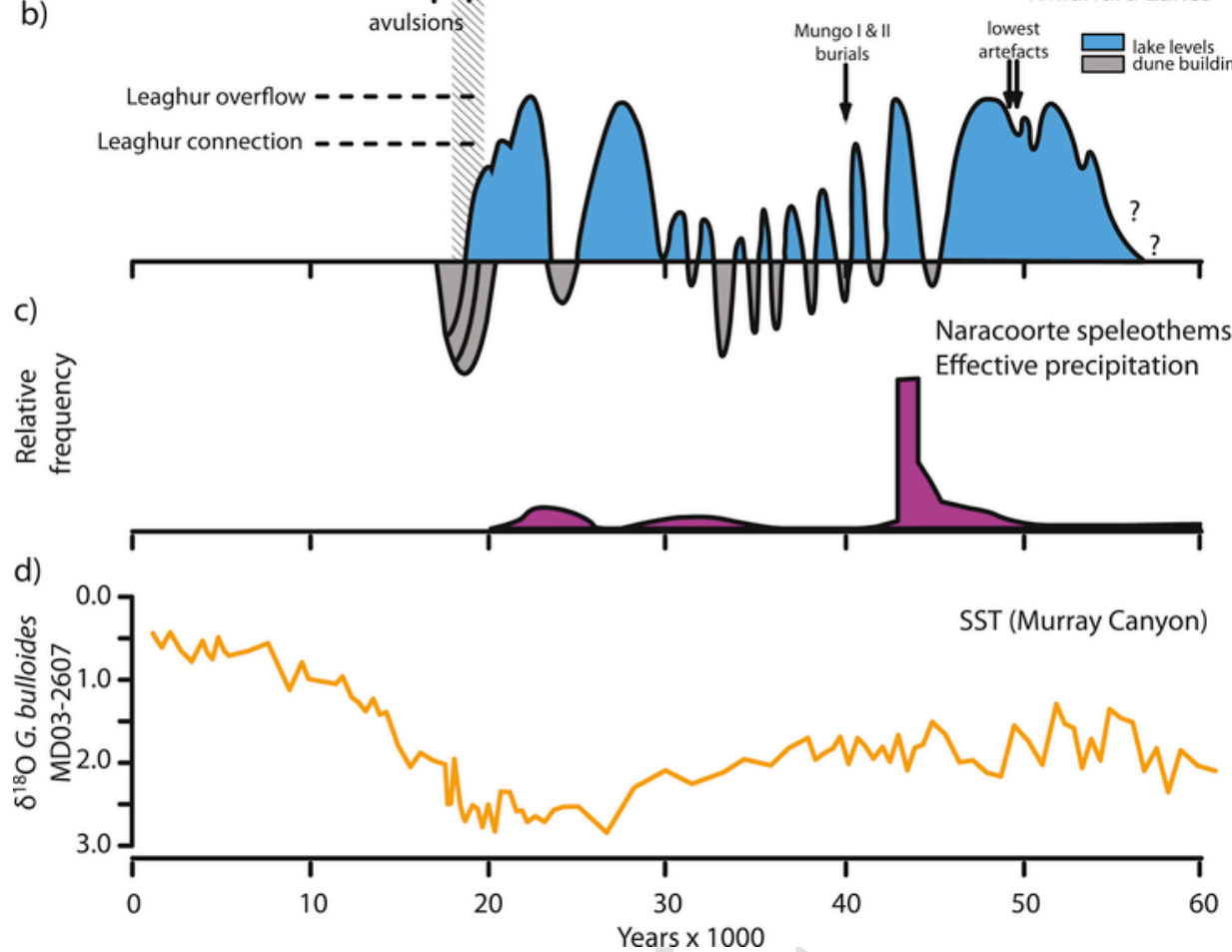

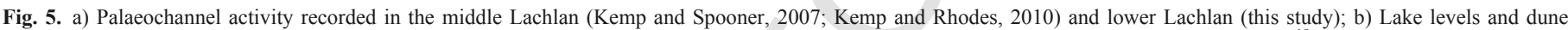

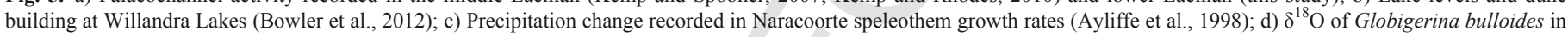
Murray Canyon core MD03-2607 (Lopes dos Santos et al., 2012).

evidence for a (possibly brief) high lake level at Willandra Lakes around $34 \mathrm{ka}$, followed by oscillating lake levels and pelletal clay deposition on the Mungo and Arumpo lunettes (Fitzsimmons et al., 2014; Bowler et al., 2012). Avulsion of Willandra Creek must have occurred before the first new channel sediments were deposited at Viela at $18.4 \pm 1.1 \mathrm{ka}$. This is consistent with the chronology of declining lake levels at Willandra Lakes. The final filling of all lakes at $22 \mathrm{ka}$ was followed by a rapid contraction of water to the uppermost Lake Mulurulu from $20.5 \mathrm{ka}$, and its final disappearance around 18 ka (Fig. 5b; Bowler et al., 2012; Fitzsimmons et al., 2014; Long et al., 2014). Some evidence for freshwater episodes in Lake Mungo until 13.8 ka (Fitzsimmons et al., 2014; Long et al., 2014) suggests that the avulsion from the Willandra channel belt may have been partial, permitting flood flows to reach the lake for some $10 \mathrm{ka}$ after the first diversion. After $20.5-18.4 \mathrm{ka}$, the Willandra Lakes provide a local, rather than a regional record of hydrological change.

In the following period, beginning 16-18 ka, the new channel belt of the Lachlan River may have carried discharges that were lower than present. Bankfull discharge of the Middle Billabong Palaeochannel at Viela can be estimated as $52 \mathrm{~m}^{3} \mathrm{~s}^{-1}$ based on the reconstructed cross-sectional area and Manning's equation, calculated using a roughness value $(n)$ of 0.05 , and slope of 0.0003 . This is roughly one-third of the gauged bankfull discharge at Hillston Weir of $150 \mathrm{~m}^{3} \mathrm{~s}^{-1}$, which is a narrow, deep and efficient channel. The large surface widths of Middle Billabong Palaeochannel, and high width-depth ratios, is consistent with a coarser sediment load than the modern river.
Presently there is a paucity of evidence for flow conditions during the terminal Pleistocene, either because the period was relatively arid, or because much of the record was removed by vigorous flows in the early Holocene. Ages between 5 and $8 \mathrm{ka}$ for the modern floodplain at Hunthawang suggest active lateral reworking of the floodplain at this time. This is consistent with evidence for larger channels on the Lachlan upstream (Nanima phase, Fig. 5a; Kemp and Rhodes, 2010), and with higher flows in the Murray River, represented by increased illite percentages in sediments of core MD03-2611 prior to capture of the sediment load by a barrier dune system at $7 \mathrm{ka}$ (Fig. $5 \mathrm{~d}$; Gingele et al., 2007; De Carli et al., Submitted). Regionally, lake levels were higher between 8-10 ka and 4.5-6.0 ka at Lake George near the headwaters of the Lachlan River (Fitzsimmons and Barrows, 2010). At lower elevations, lake levels peaked at Lake Keilambete between 7 and 9 ka (Wilkins et al., 2013), and groundwater lakes were variably fresher between 9.6 and $5.7 \mathrm{ka}$ in the Victorian western plains (Kemp et al., 2012).

\subsection{Integrating fluvial and lacustrine records in the Riverine Plain}

The timing of changes in the highlands, lakes and rivers indicates clearly that episodes of lacustrine and fluvial activity on the Riverine Plain are climatically driven, but the responses differ in fluvial and lacustrine records. Hydrologically, lakes respond to the average annual water balance, which reflects precipitation and evaporation, while the fluvial record is dominated by peak events that may be sea- 
sonal or episodic. An interesting contrast in geomorphic expression between the lakes and rivers of the lower Lachlan occurs in the early, extended LGM period. Between $34 \mathrm{ka}$ and $28 \mathrm{ka}$ impressively large meandering rivers were directly connected to the Willandra Lakes, but lake levels were oscillating or seasonally low (Fig. 5). The apparent discrepancy may be reconciled through a consideration of flow frequency. Reconstructed cross-sections of extended LGM-age channels in the Riverine Plain suggest bankfull discharges 3-4 times larger than present, but the pulse of meltwater from spring snowmelt might have been brief, with seasonally low flows that allowed source-bordering dunes to deflate from dry river beds in summer (Page, 1994). In the lake basins, the spring flood may have been sufficient to drive beach formation on the eastern shorelines, but low summer levels were probably associated with the efflorescence of salt and the deposition of pelletal clays on the lunette (Bowler, 1976). Such subtle changes in climate variability emerge from the combination of fluvial and lacustrine archives.

Despite the comparative simplicity of the lacustrine record, their dependence upon contributing waters from the river system necessitates a consideration of the fluvial response. Fluvial response to climate change is known to be complex and non-linear (Vandenberghe, 2003; Thomas, 2004). On stadial-interstadial timescales rivers respond to derivatives of climate, particularly vegetation, soil cohesion and runoff (Vandenberghe, 1995). In large catchments, major change to fluvial systems is buffered by the complexity of large catchments, from sediment storages, and by low connectivity between hillslopes and rivers. These factors generally make rivers unresponsive to changes of shorter duration than $1000 \mathrm{yr}$ (Thomas, 2004), whereas time lags created by responses of regional vegetation to climate are typically in the order of 1000s yr (Vandenberghe, 2003). Changes to groundwater levels and the changing pattern of water storages in anabranches, lagoons, and lakes on extensive lowland riverine plains will also affect the efficiency of flow transmission to lakes downstream, adding further to the complexity of palaeohydrological interpretations.

Unlike lakes, the fluvial record tends to be dominated by changes in sediment availability. Episodes of "fluvial activity" (sensu Page and Nanson, 1996) are driven by high loads of coarse sediment that promote lateral migration and the creation of wide channel belts. In contrast, periods of low sediment yield are associated with stable, suspended-load channels with low rates of channel migration and the production of minor sediment stores within the channel boundary. Phases of fluvial activity tend to occur at climatic transitions from one stable state to another, and involve widespread instability of vegetation communities and structure, incision of valley fills, and catchment soils. In southeastern Australia the most impressive phase of fluvial activity occurred at the onset of the extended LGM with a regionally synchronous transition to enlarged, laterally active rivers around $34 \mathrm{ka}$ (Kemp and Rhodes, 2010). Conditions favouring high sediment availability would then have been at their peak. Sea surface temperatures reconstructed from planktonic foramifera $G$. bulloides show that the descent into cooler conditions off South Australia began around 34 ka (Fig. 5d; Lopes dos Santos et al., 2012). Decreasing temperatures caused treelines to lower around 32 ka (Sweller and Martin, 2001; McKenzie, 1997), and glaciers advanced in the Australian Alps before $32 \mathrm{ka}$ (Headley Tarn Advance) (Barrows et al., 2001). High water availability indicated by the presence of rainforest elements in subalpine areas of the Great Dividing Range (Kershaw et al., 2007), and speleothem growth in semiarid South Australia (Fig. 5c; Ayliffe et al., 1998), indicate conditions favourable for the liberation of sediment stores in valley fills and hillslopes, and increased transport capacity of sediment to the downstream plains.
Fluvial response models explaining the cyclicity of fluvial processes through glacial cycles have been developed for glaciated or periglaciated catchments in northwest Europe, mostly on incision and aggradation sequences associated with fluvial terraces (Vandenberghe, 1995; Bridgland, 2000; Maddy et al., 2001). Similar models for the southeastern Australia have not yet been developed, and require information about the extent of cold-climate weathering, and the stability of vegetation communities under cooler temperatures and lower atmospheric $\mathrm{CO}_{2}$. At present, the chronology of fluvial change is not sufficiently precise to determine the lag in response to environmental changes, and a regional history of Pleistocene valley floor sedimentation and incision is not yet available for the highland catchments. Understanding of runoff response to temperature changes in the LGM has recently been advanced by analysis of modern-day relationships in elevation and runoff in the Australian Alps. This suggests that a $9{ }^{\circ} \mathrm{C}$ drop in temperature might be expected to produce a fourfold increase in river discharge (Reinfelds et al., 2014). Modelling these runoff responses in a range of environmental conditions is now a priority. Independent, well dated chronologies for changes in various components of the fluvial system are also needed in order to better understand fluvial responses in unglaciated, mid-latitude catchments.

\section{Conclusions}

Integrated records based on lacustrine and fluvial archives are necessary to decipher the complex geomorphic histories on lowland riverine plains. Low rates of sedimentation and tectonism in unglaciated catchments of the Riverine Plain has provided an exceptionally long time period over which to examine the effects of climate change on cyclic fluvial development. Although lacustrine records are more complete and inherently simpler, in these settings they are dependent upon complex, non-linear and lagged fluvial responses to vegetation and sediment regimes in distant catchment headwaters. Recently, new techniques for mapping the surface morphology and sub-surface sediments have substantially improved the fluvial record. The adoption of optically stimulating luminescence is now refining the chronology, particularly of events prior to the Last Glacial Maximum.

The combined evidence from lacustrine and fluvial records in the Riverine Plain is building a regionally consistent picture of hydrological conditions during the LGM. Geomorphological, geophysical and sedimentological reconstructions of channel belts in the lower Lachlan suggests that Willandra Creek was the main feeder channel to Willandra Lakes and maintained high lake levels at the Last Glacial Maximum. At, or shortly before $18.4 \mathrm{ka}$, sedimentation in the Middle Billabong Palaeochannel indicates the diversion of runoff from the Willandra Lakes to more southern areas of the Lachlan alluvial plains. The timing of this change is consistent with the record of declining water levels at Willandra Lakes. Following the LGM, the environmental records from Willandra Lakes provide a local record of hydrological change and human habitation.

\section{Acknowledgements}

We thank David Egan for granting access to the Hunthawang Homestead during its conversion from cattle station to National Park, and Jason Dillon for access to Viela. Alan Pymont and Nathan Smith assisted with fieldwork. This work was supported by the Wiradjuri Condobolin Corporation and by Australian Research Council grants (DP110103081 and LP130160748) awarded to TP, JK, AG and JO. 
Kim Cohen and an anonymous reviewer are thanked for constructive comments that improved the text.

\section{Appendix A. Supplementary data}

Supplementary data related to this article can be found at http://dx. doi.org/10.1016/j.quascirev.2017.02.015.

\section{References}

Adamson, D., Williams, M.A.J., Baxter, J.T., 1987. Complex late Quaternary history in the Nile, Murray-Darling, and Ganges basins: three river systems presently linked to the Southern Oscillation. In: Gardiner, V. (Ed.), International Geomorphology 1986 Part II. John Wiley, Chichester, pp. 875-887.

Allen, J.R., 1965. A review of the origin and characteristics of recent alluvial sediments. Sedimentology 5, 89-191.

Ayliffe, L.K., Marianelli, P.C., Moriarty, K.C., Wells, R.T., McCulloch, M.T., Mortimer, G.E., Hellstrom, J.C., 1998. 500 ka precipitation record from southeastern Australia: evidence for interglacial relative aridity. Geology 26, 147-150.

Banerjee, D., Page, K., Lepper, K., 2002. Optical dating of paleochannel deposits in the Riverine Plain, southeastern Australia: testing the reliability of existing thermoluminescence dates. Radiat. Prot. Dosim. 101, 327-332.

Barrows, T.T., Stone, J.O., Fifield, L.K., Cresswell, R.G., 2001. Late Pleistocene glaciation of the Kosciuszko Massif, Snowy Mountains, Australia. Quat. Res. 55, 179-189. http://dx.doi.org/10.1006/qres.2001.2216.

Bowler, J.M., 1971. Pleistocene salinities and climatic change: evidence from lakes and lunettes in southeastern Australia. In: Mulvaney, D.J. (Ed.), Golson J Aboriginal Man and Environment in Australia. ANU Press, Canberra, pp. 47-65.

Bowler, J.M., 1973. Clay dunes: their occurrence, formation and environmental significance. Earth Sci. Rev. 9, 315-338.

Bowler, J.M., 1976. Aridity in Australia: age, origins and expression in aeolian landforms and sediments. Earth Sci. Rev. 12, 279-310.

Bowler, J.M., 1978. Quaternary climate and tectonics in the evolution of the Riverine Plain, southeastern Australia. In: Davies, J.L., Williams, M.A.J. (Eds.), Landform Evolution in Australasia. Australian National University Press, Canberra, pp. 70-112.

Bowler, J.M., Magee, J.W., 1978. Geomorphology of the Mallee region in semi-arid northern Victoria and western New South Wales. Proc. R. Soc. Vic. 90, 5-26.

Bowler, J.M., Stockton, E.D., Walker, M.J., 1978. Quaternary stratigraphy of the Darling River near Tilpa, New South Wales. Proc. R. Soc. Vic. 90, 79-87.

Bowler, J.M., 1998. Willandra Lakes revisited: environmental framework for human occupation. Archaeol. Ocean. 33, 120-155.

Bowler, J.M., Price, D.M., 1998. Luminescence dates and stratigraphic analyses at Lake Mungo: review and new perspectives. Archaeol. Ocean. 33, 156-168.

Bowler, J.M., Johnston, H., Olley, J.M., Prescott, J.R., Roberts, R.G., Shawcross, W., Spooner, N.A., 2003. New ages for human occupation and climatic change at Lake Mungo, Australia. Nature 421, 837-840.

Bowler, J.M., Kotsonis, A., Lawrence, C.R., 2006. Environmental evolution of the Mallee region, western Murray Basin. Proc. R. Soc. Vic. 118, 161-210.

Bowler, J.M., Gillespie, R., Johnston, H., Boljkovac, K., 2012. Wind v water: glacial maximum records from the Willandra Lakes. Terra Aust. 34, 271-296.

Bridgland, D.R., 2000. River terrace systems in north-west Europe: an archive of environmental change, uplift, and early human occupation. Quat. Sci. Rev. 19, 1293-1303.

Brown, C.M., 1989. Structural and stratigraphic framework of groundwater occurrence and surface discharge in the Murray Basin, southeastern Australia. BMR J. Aust. Geol. Geophys. 11, 127-146.

Butler, B.E., 1950. A theory of prior streams as a causal factor of soil research in the Riverine Plain of south-eastern Australia. Aust. J. Agric. Res. 1, 231-252.

Butler, B.E., 1958. Depositional Systems of the Riverine Plain of South-eastern Australia in Relation to Soils. CSIRO Australia. Soil Publication no. 10.

Butler, B.E., 1959. Periodic Phenomena in Landscapes as a Basis for Soil Studies. CSIRO Soil Publications No. 14.

Butler, B.E., 1961. Ground surfaces and the history of the Riverine Plain. Aust. J. Sci. 24, 39-40.

Butler, B.E., Blackburn, G., Bowler, J.M., Laurence, C.R., Newell, J.N., Pels, S., 1973 A Geomorphic Map of the Riverine Plain of Southeastern Australia. Australian National University Press, Canberra. 39 pp and map.

Butler, B.E., 1982. A new system for soil studies. J. Soil Sci. 33, 581-595.

De Carli E., Hubble T., Penny D., Petley D., Job T., Hamilton R., Clarke S., Gadd P., Brand H.E.A., Helfensdorfer A. (Submit.). Palaeolake Mannum - a unique record of Murray Darling Basin palaeofloods and a proxy for Southern Hemisphere's Holocene hydroclimate.

Dury, G.H., 1964a. Subsurface Exploration and Chronology of Underfit Streams. U.S. Geological Survey Professional Paper 452-B USGS, Washington.

Dury, G.H., 1964b. Principles of Underfit Streams. U.S. Geological Survey Professional Paper No. 452-A USGS, Washington.
Dury, G.H., 1967. Climatic change as a geographical backdrop. Aust. Geogr. 10, 231-242.

Dury, G.H., 1976. Discharge prediction, present and former, from channel dimensions. J. Hydrol. 30, 219-245.

Dury, G.H., 1985. Attainable standards of accuracy in the retrodiction of palaeodischarge from channel dimensions. Earth Surf. Process. Landforms 10, 205-213.

Fitzsimmons, K.E., Barrows, T.T., 2010. Holocene hydrologic variability in temperate southeastern Australia: an example from Lake George, New South Wales. Holocene 20, 585-597. http://dx.doi.org/10.1177/0959683609356589.

Fitzsimmons, K.E., Stern, N., Murray-Wallace, C.V., 2014. Depositional history and archaeology of the central Lake Mungo lunette, Willandra Lakes, southeast Australia. J. Archaeol. Sci. 41, 349-364.

Fitzsimmons, K.E., Stern, N., Murray-Wallace, C.V., Truscott, W., Pop, C., 2015. The Mungo mega-lake event, semi-arid Australia: non-linear descent into the last ice age, implications for human behaviour. PLoS One 10 (6), e0127008.

Fullagar, R., Hayes, E., Stephenson, B., Field, J., Matheson, C., Stern, N., Fitzsimmons, K., 2015a. Evidence for Pleistocene seed grinding at Lake Mungo, south-eastern Australia. Archaeol. Ocean. 50 (S1), 3-19.

Fullagar, R., Hayes, E., Stephenson, B., Field, J., Matheson, C., Stern, N., Fitzsimmons, K.E., 2015b. The scale of seed grinding at Lake Mungo. Archaeol. Ocean. 50, 177-179.

Galloway, R.W., 1965. Late Quaternary climates in Australia. J. Geol. 73, 603-618

Gill, E.D., 1973. Geology and geomorphology of the Murray River region between Mildura and Renmark, Australia. Natl. Mus. Vic. Memoirs 34, 1-99.

Gingele, F., De Deckker, P., Norman, M., 2007. Late Pleistocene and Holocene climate of SE Australia reconstructed from dust and river loads deposited offshore the River Murray Mouth. Earth Planet. Sci. Lett. 255, 257-272.

Google Earth Pro 7.1.5.1557, 2015. Elevation $5000 \mathrm{M} .33^{\circ} \mathrm{S}, 144^{\circ} 53^{\prime} \mathrm{E}-33^{\circ} 49^{\prime} \mathrm{S}$, $145^{\circ} 22^{\prime} \mathrm{E}$. Available at: https://www.google.com.au/earth/.

Kellett, J.R., 1989. The Ivanhoe Block - its structure, hydrogeology and effect on groundwaters of the Riverine Plain of New South Wales. Bureau Miner. Resour. J. Aust. Geol. Geophys. 11, 333-353.

Kemp, J., 2004. Flood channel morphology of a quiet river, the Lachlan downstream from Cowra, southeastern Australia. Geomorphology 60, 171-190.

Kemp, J., Spooner, N.A., 2007. Evidence for regionally wet conditions before the LGM in southeastern Australia: OSL ages from large palaeochannels in the Lachlan valley, New South Wales. J. Quat. Sci. 22, 423-427. http://dx.doi.org/10.1002/ jqs. 1125.

Kemp, J., 2010. Downstream channel changes on a contracting, anabranching river: the Lachlan, southeastern Australia. Geomorphology 121, 231-244. http://dx.doi.org/ 10.1016/j.geomorph.2010.04.018

Kemp, J., Rhodes, E., 2010. Episodic fluvial activity of inland rivers in southeastern Australia. Quat. Sci. Rev. 29, 732-752. http://dx.doi.org/10.1016/j.quascirev.2009. 12.001.

Kemp, J., Radke, L.C., Olley, J., Juggins, S., De Deckker, P., 2012. Holocene lake salinity changes in the Wimmera, southeastern Australia, with evidence for millennial-scale climate variability. Quat. Res. 77, 65-76.

Kemp, J., Gontz, A., Pardoe, C., Pietsch, T., Olley, J., 2014a. A ground-penetrating radar survey near the excavated burial site of Kiacatoo Man. Quat. Australasia $31,32-39$.

Kemp, J., Pietsch, T.J., Olley, J., 2014b. Digging your own grave: OSL signatures in experimental graves. J. Hum. Evol. 76, 77-82.

Kershaw, A.P., McKenzie, G.M., Porch, N., Roberts, R.G., Brown, J., Heijnis, H., Orr, M.L., Jacobsen, G., Newall, P.R., 2007. A high-resolution record of vegetation and climate through the last glacial cycle from Caledonia Fen, southeastern highlands of Australia. J. Quat. Sci. 22, 481-500.

Knighton, A.D., 2014. Fluvial Forms and Processes. Routledge, London.

Langford-Smith, T., 1960. The dead river systems of the Murrumbidgee. Geogr. Rev, 50, 368-389.

Long, K., Stern, N., Williams, I.S., Kinsley, L., Wood, R., Sporcic, K., Smith, T., Fallon, S., Kokkonen, H., Moffat, I., Grün, R., 2014. Fish otolith geochemistry, environmental conditions and human occupation at Lake Mungo, Australia. Quat. Sci. Rev. 88, 82-95. http://dx.doi.org/10.1016/j.quascirev.2014.01.012.

Lopes dos Santos, R.A., Wilkins, D., De Deckker, P., Schouten, S., 2012. Late Quaternary productivity changes from offshore southeastern Australia: a biomarker approach. Palaeogeogr. Palaeoclimatol. Palaeoecol. 363, 48-56.

Maddy, D., Bridgland, D., Westaway, R., 2001. Uplift-driven valley incision and climate-controlled river terrace development in the Thames Valley, UK. Quat. Int. 79, 23-36.

Magee, J., De Deckker, P., 2001. J.M. Bowler's contribution to Australian Quaternary studies: a tribute to Jim Bowler. Quat. Int. 83-85, 1-4.

McKenzie, G.M., 1997. The late Quaternary vegetation history of the south-central highlands of Victoria, Australia. I. Sites above 900 m. Aust. J. Ecol. 22, 19-36.

Olley, J.M., Roberts, R.G., Yoshida, H., Bowler, J.M., 2006. Single-grain optical dating of grave-infill associated with human burials at Lake Mungo, Australia. Quat. Sci. Rev. 25, 2469-2474

Page, K.J., Nanson, G.C., 1982. Concave-bank benches and associated floodplain formation. Earth Surf. Process. Landforms 7, 529-543. 
Page, K.J., Nanson, G.C., Price, D.M., 1991. Thermoluminescence chronology of late Quaternary deposition on the Riverine Plain of south-eastern Australia. Aust. Geogr. 22, 14-23. http://dx.doi.org/10.1080/00049189108703017.

Page, K.J., 1994. Late Quaternary Stratigraphy of the Riverine Plain. Unpublished PhD thesis University of Wollongong, Wollongong.

Page, K.J., Nanson, G.C., 1996. Stratigraphic architecture resulting from late Quaternary evolution of the Riverine Plain, south-eastern Australia. Sedimentology 43, 927-945. http://dx.doi.org/10.1111/j.1365-3091.1996.tb01512.x.

Page, K., Nanson, G., Price, D., 1996. Chronology of Murrumbidgee River palaeochannels on the Riverine Plain, southeastern Australia. J. Quat. Sci. 11, 311-326. http://dx.doi.org/10.1002/(SICI)1099-1417(199607/08)11: 4<311::AID-JQS256>3.0.CO;2-1.

Page, K.J., Dare-Edwards, A.J., Owens, J.W., Frazier, P.S., Kellett, J., Price, D.M., 2001. TL chronology and stratigraphy of riverine source bordering sand dunes near Wagga Wagga, New South Wales, Australia. Quat. Int. 83, 187-193. http://dx.doi. org/10.1016/S1040-6182(01)00039-8.

Page, K.J., Nanson, G.C., Frazier, P.S., 2003. Floodplain formation and sediment stratigraphy resulting from oblique accretion on the Murrumbidgee River, Australia. J. Sediment. Res. 73, 5-14.

Page, K., Kemp, J., Nanson, G.C., 2009. Late Quaternary evolution of Riverine Plain palaeochannels, southeastern Australia. Aust. J. Earth Sci. 56, S19-S33. http://dx. doi.org/10.1080/08120090902870772.

Pels, S., 1964. The present and ancestral Murray River system. Aust. Geogr. Stud. 2, 111-119.

Pels, S., 1966. Late Quaternary chronology of the Riverine Plain of southeastern Australia. J. Geol. Soc. Aust. 13, 27-40.

Petherick, L., Bostock, H., Cohen, T.J., Fitzsimmons, K., Tibby, J., Fletcher, M.S., Moss, P., Reeves, J., Mooney, S., Barrows, T., Kemp, J., 2013. Climatic records over the past $30 \mathrm{ka}$ from temperate Australia-a synthesis from the Oz-INTIMATE workgroup. Quat. Sci. Rev. 74, 58-77.

Pietsch, T.J., Nanson, G.C., 2011. Bankfull hydraulic geometry; the role of in-channel vegetation and downstream declining discharges in the anabranching and distributary channels of the Gwydir distributive fluvial system, southeastern Australia. Geomorphology 129, 152-165.

Reeves, J.M., Barrows, T.T., Cohen, T.J., Kiem, A.S., Bostock, H.C., Fitzsimmons, K.E., Jansen, J.D., Kemp, J., Krause, C., Petherick, L., Phipps, S.J., 2013. Climate variability over the last 35,000 years recorded in marine and terrestrial archives in the Australian region: an OZ-INTIMATE compilation. Quat. Sci. Rev. 74, 21-34.

Reinfelds, I., Swanson, E., Cohen, T., Larsen, J., Nolan, A., 2014. Hydrospatial assessment of streamflow yields and effects of climate change: Snowy Mountains, Australia. J. Hydrol. 512, 206-220. http://dx.doi.org/10.1016/j.jhydrol.2014.02.038.

Risbey, J.S., Pook, M.J., McIntosh, P.C., Wheeler, M.C., Hendon, H.H., 2009. On the remote drivers of rainfall variability in Australia. Mon. Weather Rev. 137, 3233-3253.

Rutherfurd, I.D., 1994. Inherited controls on the forms of a large, low energy river: the Murray River, Australia. In: Schumm, S.A., Winkley, B.R. (Eds.), The Variability of Large Alluvial Rivers. American Society of Civil Engineers, New York, pp. $177-197$.

Schaetzl, R.J., Thompson, M.L., 2015. Soils: Genesis and Geomorphology. Cambridge University Press, New York. 778 pp.

Schumm, S.A., 1960. The effect of sediment type on the shape and stratification of some modern fluvial deposits. Am. J. Sci. 258, 177-184.
Schumm, S.A., 1968. River Adjustment to Altered Hydrologic Regimen - Murrumbidgee River and Paleochannels, Australia. U. S. Geol. Surv. Prof. Pap. 598. Schumm, S.A., 1969. River metamorphosis. J. Hydraulics Div. Am. Soc. Civ. Eng. 95 (HY1), 255-273.

Schumm, S.A., 1972. Fluvial palaeochannels. In: Rigby, J.K., Hamblin, K. (Eds.), Recognition of Ancient Sedimentary Environments. Society of Economic Paleontologists and Mineralogists Special Publication No. 16.

Schumm, S.A., 1978. Reconstructing paleochannel morphologic and flow characteristics: methodology, limitations, and assessment. In: Miall, A.D. (Ed.), Fluvial Sedimentology. Canadian Society of Petroleum Geologists, Calgary, pp. 703-721.

Schumm, S.A., 1985. Patterns of alluvial rivers. Annu. Rev. Earth Planet. Sci. 13, 5-27.

Schumm SA, Erskine WD, Tilleard JW. 1996. Morphology, hydrology, and evolution of the anastomosing Ovens and King Rivers, Victoria, Australia. Geological Society of America Bulletin 108, 1212-1224.Slee, A., Shulmeister, J., 2015. The distribution and climatic implications of periglacial landforms in eastern Australia. J. Quat. Sci. 30, 848-858. http://dx.doi.org/10.1002/jqs.2823.

Stern, N., Tumney, J., Fitzsimmons, K.E., Kajewski, P., 2013. Strategies for investigating human responses to changes in landscape and climate at Lake Mungo in the Willandra Lakes, southeast Australia. In: Frankel, D., Webb, J., Lawrence, S. (Eds.), Archaeology in Environment and Technology: Intersections and Transformations. Routledge, New York, pp. 31-50.

Stern, N., 2015. The archaeology of the Willandra. In: McGrath, A., Webb, M.A. (Eds.), Long History, Deep Time: Deepening Histories of Place. ANU Press \& Aboriginal History, Canberra, pp. 221-240.

Stone, T., 2006. The late-Holocene origin of the modern Murray River course, southeastern Australia. Holocene 16, 771-778. http://dx.doi.org/10.1191/ $0959683606 \mathrm{~h} 1971 \mathrm{rr}$.

Sweller, S., Martin, H.A., 2001. A 40,000 year vegetation history and climatic interpretations of Burraga Swamp, Barrington Tops, New South Wales. Quat. Int. 83-85, 233-244.

Thomas, M.F., 2004. Landscape sensitivity to rapid environmental change - a Quaternary perspective with examples from tropical areas. Catena 55, 107-124.

Thorne, A., Grün, R., Mortimer, G., Spooner, N.A., Simpson, J.J., McCulloch, M., Taylor, L., Curnoe, D., 1999. Australia's oldest human remains: age of the Lake Mungo 3 skeleton. J. Hum. Evol. 36, 591-612.

Vandenberghe, J., 1995. Timescales, climate and river development. Quat. Sci. Rev. 14, 631-638.

Vandenberghe, J., 2003. Climate forcing of fluvial system development: an evolution of ideas. Quat. Sci. Rev. 22, 2053-2060.

Westaway M.C., Olley J. and Grün R., At least 17,000 years of coexistence: Modern humans and megafauna at the Willandra Lakes, South-Eastern Australia, Quat. Sci. Rev. 157, 2017, 206-211.Weston, E., Szabó, K., Stern, N., 2015, http://dx.doi.org/ 10.1016/j.quaint.2015.11.048. Pleistocene shell tools from Lake Mungo lunette, Australia: identification and interpretation drawing on experimental archaeology. Quat. Int.

Wilkins, D., Gouramanis, C., De Deckker, P., Fifield, L.K., Olley, J., 2013. Holocene lake-level fluctuations in Lakes Keilambete and Gnotuk, southwestern Victoria, Australia. Holocene 23, 783-795. http://dx.doi.org/10.1177/0959683612471983. 